\section{Winterfat Seedlings Emerge Best from Shallow Seeding, Moderately Dry Soil ${ }^{1}$}

H. W. SPRINGFIELD

Range Scientist, Rocky Mountain Forest and Range Experiment Station, 2 Albuquerque, New Mexico.

${ }^{1}$ Received October 29, 1970; accepted for publication November 4, 1970. ${ }^{2}$ Forest Service, U. S. Department of Agriculture, with central headquarters maintained at Fort Collins in cooperation with Colorado State University; research reported here was conducted at Albuquerque in cooperation with the University of New Mexico.

\section{Highlight}

Seeds of winterfat (Eurotia lanata) were planted at four depths in three soils held at five moisture levels. Emergence was best from the $1 / 16^{-i n c h}$ depth, and when soil moisture was nearer field capacity than saturation.

Winterfat (Eurotia lanata (Pursh) Moq.) is a desirable shrub for revegetating semiarid ranges. Results of direct seeding of winterfat in New Mexico, however, have been erratic. One reason for lack of success has been unfavorable weather following seeding.
Another reason may have been that the seeds were covered too deeply. Recently it was found that, in wet soil at least, establishment of winterfat seedlings is best when seeds are planted on the surface (Springfield, 1970). Wilson (1931) also observed that winterfat fruits would germinate on the soil surface if there were several days of wet weather. Other investigators have reported better results from shallow than from deep planting (Hilton, 1941; Riedl et al., 1964; Statler, 1967).

Objcctives of this study were to determine the effects of depth of seeding, soil texture, and soil moisture level on seedling emergence. 


\section{Methods}

Seeds were planted July 24, 1969, in small plastic pots. Treatments were completely randomized in a $3 \times 4 \times 5$ factorial design. Each combination of depth, soil, and moisture level (Table 1) was replicated three times. Ten viable seeds were planted in each pot. The seeds, threshed by hand from fruits collected November 1, 1968 near Corona, New Mexico, numbered 189,000 per pound.

Seeding depths--which were precisely measured-were $1 / 16,1 / 8,1 / 4$, and $1 / 2$ inch.

Five of the moisture levels in Table 1 (all except wilting) were included in the tests. These levels were achieved by adding to a constant weight of ovendried soil the calculated amount of distilled water. The gross weight of each pot-soil plus water for a specific moisture level-was marked on the pot. To insure that moisture levels remained essentially as prescribed throughout the experiment, evaporation losses were minimized by suspending a sheet of plastic 3 inches above the pots. Moisture losses, determined by daily weighing, were negligible. Water was added when the loss exceeded 0.5 gram.

The experiment was conducted on laboratory benches at room temperature. Air and soil temperatures were monitored. Soil temperatures were measured with thermistors placed at different depths (Swanson, 1967). There were no significant differences in temperatures among moisture levels, seeding depths, or soils. Average temperatures during the 2 weeks when seedlings were emerging were:

\begin{tabular}{lcc}
\hline & Range & Mean \\
\hline Air & 68.5 to 83.7 & 75.2 \\
Soil & 67.6 to 78.0 & 72.4 \\
\hline
\end{tabular}

Seedlings, counted each day until emergence stopped, August 4, 1969, were considered emerged when the cotyledons were $1 / 2$ inch above the soil surface. Seedling emergence percentages were transformed to arc sin for analysis of variance.

\section{Results and Discussion}

The $1 / 16$-inch planting depth was substantially better than the other depths (Table 2). Very few seedlings emerged from $1 / 4$ inch (mainly in the clay soil), and not a single seedling came up from seeds planted $1 / 2$ inch deep.

Seedling emergence was significantly better in the clay and loamy sand than in the sandy loam. In a previous study

Table 1. Characteristics of three soils ${ }^{1}$ tested for emergence of winterfat seedlings in northern New Mexico.

\begin{tabular}{|c|c|c|c|c|c|c|c|c|}
\hline \multirow{3}{*}{$\begin{array}{c}\text { Soil } \\
\text { identification } \\
\text { and location }\end{array}$} & \multirow[b]{3}{*}{ Texture } & \multirow{3}{*}{$\begin{array}{c}\mathrm{pH} \text { (satu- } \\
\text { ration paste) }\end{array}$} & \multicolumn{6}{|c|}{ Moisture percentage, by condition } \\
\hline & & & \multicolumn{4}{|c|}{ Level of saturation } & \multirow{2}{*}{$\begin{array}{c}\text { Field } \\
\text { capacity } \\
(1 / 3 \text { bar) }\end{array}$} & \multirow{2}{*}{$\begin{array}{l}\text { Wilting } \\
\text { (15 bar) }\end{array}$} \\
\hline & & & Full & $\%$ & $2 / 3$ & $1 / 2$ & & \\
\hline $\begin{array}{l}\text { Silver Hill } \\
8 \mathrm{mi} . \text { W of } \\
\text { Magdalena }\end{array}$ & Loamy sand & 7.6 & 27.4 & 22.8 & 18.3 & 13.7 & 6.4 & 3.6 \\
\hline $\begin{array}{l}\text { QRA } \\
8 \mathrm{mi} . \mathrm{W} \text { of } \\
\text { Santa } \mathrm{Fe}\end{array}$ & Sandy loam & 7.1 & 30.6 & 25.5 & 20.4 & 15.3 & 11.8 & 5.3 \\
\hline $\begin{array}{l}\text { Wingate } \\
18 \mathrm{mi} . \mathrm{E} \text { of } \\
\text { Gallup }\end{array}$ & Clay & 7.8 & 46.8 & 39.0 & 31.2 & 23.4 & 18.9 & 11.9 \\
\hline
\end{tabular}

${ }^{1}$ Moisturc-holding characteristics of the soils determined by Ralph E. Campbell, Soil Scientist, Rocky Mountain Forest and Range Experiment Station, Albuquerque.

more seedlings became established in the sandy loam than in the other two soils, but most of those seedlings resulted from seeds planted on the surface of wet soil (Springfield, 1970).

Seedling emergence was inversely related to moisture level. Wintcrfat secds on blotters in petri dishes germinated best when there was little or no moisture stress (Springfield, 1968). In this experiment, however, emergence was better in moderately dry than in wet soil. Averages for all soils and depths show emergence declined gradually from $1 / 2$ to $2 / 3$ saturation, then dropped rather sharply. Emergence was least when soils were $5 \%$ or fully saturated.
Differences in emergence from the three depths of seeding were not consistent throughout the range in moisture studied. Likewise, the relationship between depths of seeding and soils was not consistent. Seeds planted 1/16 inch deep produced as many seedlings in loamy sand as in clay soil. When seeds were planted $1 / 8$ or $1 / 4$ inch deep, emergence was best in the clay. Production of seedlings in the sandy loam soil was proportionately much poorer from seeds planted $1 / 8$ or $1 / 4$ inch than from those planted $1 / 16$ inch.

The really puzzling question is: why was seedling emergence so poor in wet soil? Even the seeds planted only $1 / 16$

Table 2. Percent emergence of winterfat seedlings from seeds planted at three depths in three soils held at five moisture levels. ${ }^{1}$

\begin{tabular}{|c|c|c|c|c|c|}
\hline \multirow{3}{*}{$\begin{array}{c}\text { Soil } \\
\text { identification } \\
\text { and depth } \\
\text { of seeding }\end{array}$} & \multicolumn{5}{|c|}{ Percent emergence, by moisture level } \\
\hline & \multicolumn{4}{|c|}{ Level of saturation } & \multirow{2}{*}{$\begin{array}{c}\text { Field } \\
\text { capacity }\end{array}$} \\
\hline & Full & $5 \%$ & $2 / 3$ & $1 / 2$ & \\
\hline \multicolumn{6}{|l|}{ Silver Hill } \\
\hline $1 / 16$ inch & $13 \mathrm{~b}$ & $23 \mathrm{~b}$ & $87 \mathrm{a}$ & $80 a$ & $87 \mathrm{a}$ \\
\hline $1 / 8$ inch & $0 \mathrm{c}$ & $7 \mathrm{c}$ & $67 \mathrm{a}$ & $40 \mathrm{~b}$ & $43 \mathrm{~b}$ \\
\hline $1 / 4$ inch & $0 \mathrm{a}$ & $0 \mathrm{a}$ & $3 \mathrm{a}$ & $0 \mathrm{a}$ & $7 \mathrm{a}$ \\
\hline \multicolumn{6}{|l|}{ QRA } \\
\hline $1 / 16$ inch & $7 \mathrm{c}$ & $13 \mathrm{bc}$ & $23 \mathrm{~b}$ & $67 \mathrm{a}$ & 73 a \\
\hline $1 / 8$ inch & $3 \mathrm{~b}$ & $3 \mathbf{b}$ & $7 \mathrm{ab}$ & $17 \mathrm{a}$ & $20 \mathrm{a}$ \\
\hline $1 / 4$ inch & 0 & 0 & 0 & 0 & 0 \\
\hline \multicolumn{6}{|l|}{ Wingate } \\
\hline $1 / 16$ inch & $23 \mathrm{c}$ & $27 \mathrm{c}$ & $50 \mathrm{~b}$ & 87 a & 87 a \\
\hline $1 / 8$ inch & $17 \mathrm{~b}$ & $20 \mathrm{~b}$ & $57 \mathrm{a}$ & $60 \mathrm{a}$ & $57 \mathrm{a}$ \\
\hline $1 / 4$ inch & $0 \mathrm{~b}$ & $0 \mathrm{~b}$ & $10 \mathrm{ab}$ & $10 \mathrm{ab}$ & $23 \mathrm{a}$ \\
\hline
\end{tabular}

${ }^{1}$ Numbers in the same row, followed by the same letter, are not significantly different at the $5 \%$ level of probability. 
inch deep failed to produce many seedlings in saturated or near-saturated soil. Poor aeration is perhaps the most obvious explanation, but undefined soil physical factors also may be involved. In a previous experiment, germinated seeds and fairly well-developed seedlings were found curled and compressed beneath a layer of soil at the same depth the seeds had been planted. The sccds had germinated, but the young seedlings did not have enough thrusting capacity to push through the soil. Investigations have not progressed to the point where combinations of soil and moisture that most restrict the upward growth of winterfat seedlings can be specified. The results do suggest, however, that clay was less of a barrier to an emerging seedling than either the sandy loam or loamy sand. Only in the clay soil did a reasonable number of seedlings emerge from the $1 / 4$-inch depth, and only in the clay was there fair emergence from seeds planted $1 / 8$ inch deep in wet soil. Of course, soil characteristics other than texture may have affected the results.

Evidence from corollary investigations indicates that density of the germination medium, as well as aeration, probably influences the emergence of winterfat seedlings. Seeds were planted $10 \mathrm{~mm}$ deep in sand, perlite, and vermiculite held at $1 / 2,3 / 4$, and full satura- tion. Practically no seedlings emerged in the sand, regardless of moisture content. Percent emergence in the less dense media was:

\begin{tabular}{ccc}
\hline Saturation level & Perlite & Vermiculite \\
\hline $1 / 2$ & 50 & 100 \\
$3 / 4$ & 30 & 95 \\
Full & 10 & 80 \\
\hline
\end{tabular}

\section{Conclusions}

Shallow planting of winterfat seeds is important, regardless of soil moisture content or kind of soil. Fewer seedlings emerged in wet soil than in moderately dry soil, even when seeds were planted shallow. Soil texture, and possibly other soil characteristics, may affect emergence. Moreover, although the explanations are not clearcut, there were indications that (1) winterfat is somewhat sensitive to deficient aeration, and (2) dense soil, especially when it is wet, impedes cmergence of winterfat seedlings.

Future investigations should be aimed at increasing knowledge about:

1. the inherent capacity of the seedling to break through the soil surface;

2. the effects of acration on germination and seedling development; and

3. the physical characteristics of var- ious soils, wet and dry, in relation to seedling emergence.

\section{Literature Cited}

Hilton, James W. 1941. Effects of certain micro-ecological factors on the germinability and early development of Eurotia lanata. Northwest Sci. 15:86-92.

Riedl, W. A., K. H. Asay, J. L. Nelson, and G. M. Telwar. 1964. Studies of Eurotia lanata (winterfat). Wyo. Agr. Exp. Sta. Bull. 425, 18 p.

SPRINGFIELD, H. W. 1968 . Germination of winterfat seeds under different moisture stresses and temperatures. J. Range Manage. 21:314-316. SPRINGFIELd, H. W. 1970. Emergence and survival of winterfat seedlings from four planting depths. U. S. D. A. Forest Service Res. Note RM-162, 4 p. Rocky Mtn. Forest and Range Exp. Sta., Fort Collins, Colo.

Statler, Glen D. 1967. Eurotia lanata establishment trials. J. Range Manage. 20:253-255.

Swanson, Robert H. 1967. A lowcost instrument to measure temperature or resistance accurately. U. S. D. A. Forest Service Res. Note RM-80, 4 p. Rocky Mtn. Forest and Range Exp. Sta., Fort Collins, Colo.

Wilson, C. P. 1931. The artificial reseeding of New Mexico ranges. $\mathbf{N}$. Mex. Agr. Exp. Sta. Bull. 189, 37 p. 